\title{
Nutrient Intake, Digestibility and Performance of Male Kacang Goats Fattened by Complete Sillage
}

\section{Paulus Klau Tahuk*, Gerson Frans Bira, Krisantus Ronal Mude Lopi, Ardhian Bosharry Nenabu, Nofrianus Kolo}

Department of Animal Science, Faculty of Agriculture, Universitas Timor, Jl. El Tari, Km-9 Kefamenanu, North Central Timor, East Nusa Tenggara, Indonesia.

\begin{abstract}
The study aims to determine the performance of young male Kacang goats fattened by complete silage. There were 12 young male Kacang goats used in this study with initial body weight of 10-12 kg. The study used a Completely Randomized Design with 3 treatments for each TI: 45\% Natural Grass + Leucaena leucocephala 20\% + corn flour 25\% + bran pollard 10\%; T2: Sorghum bicolor L. Moench 45\% + L. leucocephala 20\% + corn flour 25\% + bran pollard 10\%; T3: Pennisetum purpuphoides $45 \%+$ L. leucocephala $20 \%+$ corn flour $25 \%+$ bran pollard $10 \%$. The data was analyzed by analysis of variance. The results showed that the use of complete silage made from different forages did not have a significant effect on the feed intake and digestibility of the male Kacang goats, except digestibility of ether extract $(\mathrm{P}<0.05)$. Daily body weight gain of $\mathrm{T} 2$ treatment higher than $\mathrm{T} 1$ treatment $(\mathrm{P}<0.05)$, but was relatively the same with T3 treatment. As well as the T1 treatment was relatively the same with T3 treatment. The feed conversion and efficiency provided relatively the same results of the three treatments. It can be concluded that the male Kacang goats which obtained complete silage composed of natural grass, S. bicolor L.Moench and P. purpuphoides in have not had a significant effect on the feed intake and digestibility of nutrients, except on the digestion of ether extract. The daily body weight gain of the goats that received complete silage with Sorghum bicolor L. Moench-based forage can be increased, but the feed conversion and efficiency used have relatively similar effects.
\end{abstract}

Keywords | Complete silage, digestibility, Feed intake, Male Kacang goat, Performance

Received | February 21, 2021; Accepted | June 27, 2021; Published | November 01, 2021

${ }^{*}$ Correspondence | Paulus Klau Tahuk, Department of Animal Science, Faculty of Agriculture, Universitas Timor, J1. El Tari, Km-9 Kefamenanu, North Central Timor, East Nusa Tenggara, Indonesia; Email: Paulklau@yahoo.co.id

Citation | Tahuk PK, Bira GF, Lopi KRM, Nenabu AB, Kolo N (2021). Nutrient intake, digestibility and performance of male kacang goats fattened by complete silage. Adv. Anim. Vet. Sci. 9(12): 2147-2156.

DOI | http://dx.doi.org/10.17582/journal.aavs/2021/9.12.2147.2156

ISSN (Online) | 2307-8316; ISSN (Print) | 2309-3331

Copyright (C 2021 Tahuk et al. This is an open access article distributed under the Creative Commons Attribution License, which permits unrestricted use, distribution, and reproduction in any medium, provided the original work is properly cited.

\section{INTRODUCTION}

$\mathrm{K}$ acang goat is a type of small ruminant and Indonesian local goat that has the potential to be developed commercially. Besides being developed commercially to increase the income of the community and used to meet animal protein intake, goat farming can be used as a family savings from which the goats can be sold at any time to meet the needs of family.

The limiting factor in maintaining and increasing the productivity of Kacang goat in semi-arid regions, one of which is East Nusa Tenggara, is the availability of forages. In the rainy season, the quantity and quality of the feed is available adequately, while in the dry season the availability of feed becomes a serious problem that greatly disrupts the livestock productivity (Tahuk and Dethan, 2010). The productivity of Kacang goat in the tropics generally fluctuates depending on the season. Fluctuating quantity and quality of feed can result in decreased levels of livestock productivity such as high mortality and low rates of livestock growth (Kurniawan et al., 2019). This situation has a significant effect on the achievement of optimal production of Kacang goat.

Considering the aforementioned condition, it is necessary 
to provide alternative feed supply so that there is no decline in livestock productivity in the dry season. One of the alternative feed provisions that can be done is the development of complete silage technology. Besides as a food barn to meet the needs of livestock in the dry season, the application of complete silage technology is also one of the strategies to optimize the utilization of abundance of feed during the rainy season in the tropics to be given to livestock during the dry season.

Silage is a method of preserving feed through anaerobic fermentation process by the activity of lactic acid bacteria (Santoso et al., 2011). There are two types of silage: (1) single silage which is made from one ingredient such as legume only or grass types only; and (2) complete silage consisting of various ingredients such as a mixture of grass or legume. In general, the level of dissolved sugar in the ensiling process (ensilage) will cause less effective work of lactic acid bacteria (Jasin, 2014). Feed ingredients that have higher dissolved sugar levels will have a positive impact on the ensilase process. On the other hand, the lower the dissolved sugar from the feed ingredients, it will inhibit the ensilase process because microbial activity is not maximal. Therefore the addition of additive (silage additive) is needed to accelerate the ensiling process and provide complete nutrition to meet the needs of livestock. Complete silage is promising to be developed since it can meet the nutritional needs of livestock if it is formulated adequately without other feed ingredients.

One of the factors that needs to be considered in the process of making complete silage is the availability of raw ingredients for not all feed ingredients can be used as the basis for making silage. Silage feedstuffs are usually edible and generally favored by livestock, and has an adequate content of soluble carbohydrates.

Forage as the basic for making complete silage can have different effects both on the quality of complete silage produced and on the livestock productivity. In this study, there are several types of ingredients utilized including Sorghum bicolor L. Moench, Pennisetum purpuphoides and natural grass. These ingredients are chosen because of their abundant availability of nutrients and biomass in the rainy season and were generally favored by livestock.

An adequate quality of complete silage can increase feed intake and digestibility, which in turn can contribute to increasing the productivity of Kacang goat. Tahuk and Bira (2020) reported carcass percentage of male Kacang goat fed to complete silage can be improved. However, there is still insufficient information related to the use of complete silage for fattening Kacang goat. Therefore, this study aims to determine the productivity of male Kacang goat which obtains complete silage made from natural grass, Sorghum

bicolor L. Moench and Pennisetum purpuphoides.

\section{MATERIALS AND METHODS}

\section{TIME, LIVESTOCK, FEED AND RESEARCH DESIGN}

This study was conducted for 8 months starting from the preparation, data collection and reporting that took place at the Experimental Cage, Faculty of Agriculture, Universitas Timor. An analysis of the quality of feed ingredients and complete silage was carried out at Feed Chemistry Laboratory, Faculty of Animal Husbandry, Universitas Nusa Cendana. There were 12 young male Kacang goats used in this study with initial body weight of $10-12 \mathrm{~kg}$.

The feed used was complete silage composed of natural grass, Sorghum bicolor L. Moench, Pennisetum purpuphoides, corn flour and bran pollard. The ration was prepared on the basis of the needs of young goats with a body weight of $10 \mathrm{~kg}$ (Kearl, 1982). Furthermore, the male Kacang goats were given mineral premixes to avoid mineral deficiencies. The expected Daily Body Weight Gain (DBWG) was 75 $\mathrm{g} /$ head/day.

This study utilized a Completely Randomized Design (CRD), with 3 ration treatment groups and each treatment consisted of 4 goats. The following were silage ingredients of the treatment given to the male Kacang goats:

TI: Natural grass 45\% + Leucaena leucocephala $20 \%+$ corn flour 25\% + bran pollard 10\%

T2: Sorghum bicolor L. Moench 45\% + Leucaena leucocephala $20 \%+$ corn flour $25 \%+$ bran pollard $10 \%$

T3: Pennisetum purpuphoides 45\% + Leucaena leucocephala $20 \%+$ corn flour $25 \%+$ bran pollard $10 \%$

The ration is prepared with a composition of different levels of crude protein with energy iso (TDN). The crude protein level of T1 treatment was $13.7522 \%$, T2 was $14.3552 \%$, and T3 treatment was $14.1437 \%$ with an average of TDN was $70.6135 \%$ (Tables 1 and 2).

There were 12 individual cages with a size of $70 \times 150 \mathrm{~cm}$ used equipped with separate feed and drinking water, digital livestock scales with a sensitivity of $0.1 \mathrm{~kg}, 2 \mathrm{~kg}$ capacity feed scales with a sensitivity of $10 \mathrm{~g}$, stool container, $1 \mathrm{~mm}$ filter mesh wiley mill grinder for grinding feed and feces (stool) samples, and 1 unit of proximate analyzer.

\section{RESEARCH PROCEDURE}

\section{COMPLETE SILAGE MAKING}

Natural grass, Sorghum bicolor L. Moench and Pennisetum purpuphoides were harvested early in the flowering period and chopped at $\pm 3-5 \mathrm{~cm}$ long. The chopped three forages were spread on a tarpaulin based on each treatment. The 
next step was that the chopped natural grass or Sorghum bicolor L. Moench or Pennisetum purpuphoides was mixed with Leucaena leucocephala which had been chopped with the same size. Silage additives in the form of corn flour and bran pollard were then weighed as needed and sprinkled evenly over the chopped forage. The chopped forage and the silage additive were stirred until evenly mixed. The mixture was inserted gradually into the plastic drum silo while compacted gradually to release as much oxygen as possible. A fully filled silo with a mixture of the forage and the additive was then stored (ensilage) in a room with room temperature for 21 days. After the ensilage process for 21 days, the silo was opened, and complete silage produced was aerated and then adapted to the male Kacang goats based on the observed treatment. In addition, the physical and chemical qualities of complete silage were analyzed.

Table 1: The Chemical composition of the complete silage ${ }^{1}$.

\begin{tabular}{|c|c|c|c|c|c|c|c|c|c|c|c|c|}
\hline \multirow{3}{*}{$\begin{array}{l}\text { Treat- } \\
\text { ments }\end{array}$} & \multirow[b]{2}{*}{ DM (\%) } & \multirow[b]{2}{*}{ OM } & \multirow[b]{2}{*}{$\mathrm{CP}$} & \multicolumn{9}{|c|}{ Nutrient composition (\%) } \\
\hline & & & & $\mathrm{CF}$ & $\mathrm{EE}$ & $\mathrm{CHO}$ & NFE & ASH & $\mathrm{TDN}^{*}$ & GE & & ME \\
\hline & & $\%$ of DN & & & & & & & & $\begin{array}{l}\text { MJ/ } \\
\text { Kg.DM }\end{array}$ & $\begin{array}{l}\text { Kcal/ } \\
\text { kg.DM }\end{array}$ & $\begin{array}{l}\mathrm{Kcal} / \\
\mathrm{kg} . \mathrm{DM}\end{array}$ \\
\hline $\mathrm{T} 1^{2}$ & 37.361 & 86.771 & 9.895 & 27.264 & 5.236 & 71.595 & 44.331 & 13.229 & 82.00 & 16.581 & 3947.920 & 2731.393 \\
\hline $\mathrm{T}^{3}{ }^{3}$ & 33.793 & 88.148 & 13.818 & 14.867 & 7.297 & 67.033 & 52.167 & 11.852 & 78.00 & 17.435 & 4151.223 & 3382.528 \\
\hline $\mathrm{T} 3^{4}$ & 32.491 & 84.841 & 11.112 & 22.051 & 6.981 & 66.748 & 44.697 & 15.159 & 76.00 & 16.622 & 3957.663 & 2940.450 \\
\hline
\end{tabular}

Note: ${ }^{1}$ Results of Feed Chemistry Laboratory Analysis, Faculty of Animal Husbandry,Nusa Cendana University (2019); ${ }^{2} \mathrm{~T} 1: 45 \%$ Natural grass $+20 \%$ L. leucocephala $+25 \%$ cornflour $+10 \%$ bran pollard; ${ }^{3}$ T2: $45 \%$ Sorghum bicolor (L.) Moench) $+20 \%$ L. leucocephala + cornflour 25\% + 10\% bran pollard; ${ }^{4} \mathrm{~T} 3: 45 \%$ P. purpuphoides + 20\% L. leucocephala + 25\% cornflour + 10\% bran pollard; DM: Dry matter; OM: organic matter; Crude protein; CF: Crude fiber; Extract eter; NFE: nitrogen-free extract; TDN: Total digestible nutrients; GE: Gross energy; ME:Metabolism energy. *In accordance with the equation Hartadi et al. (1980).

Table 2: Composition of research rations (basic DM).

\begin{tabular}{llll} 
Treatment/feedstuff & $\begin{array}{l}\text { Ingredients } \\
\text { proportion of } \\
\text { feed }\end{array}$ & $\begin{array}{l}\text { Nutrient } \\
\text { composition of } \\
\text { ration }\end{array}$ \\
& & CP (\%) & $\begin{array}{l}\text { TDN } \\
\text { (\%) }\end{array}$ \\
\hline T1 & & & \\
\hline Natural grass & 45 & 5.01 & 26.10 \\
\hline L. Leucocphala & 20 & 5.13 & 15.96 \\
\hline Flour Corn & 25 & 1.97 & 20.94 \\
\hline Bran pollard & 10 & 1.64 & 7.48 \\
\hline Total & 100 & 13.75 & 70.49 \\
\hline T2 & & & \\
\hline Sorghum bicolor (L.) Moench & 45 & 5.40 & 26.96 \\
\hline L. Leucocphala & 20 & 5.13 & 15.96 \\
\hline Flour Corn & 25 & 1.97 & 20.94 \\
\hline Bran pollard & 10 & 1.6412 & 7.48 \\
\hline Total & 100 & 14.14 & 71.33 \\
\hline T3 & & & \\
\hline Pennisetum purpuphoides & 45 & 5,61 & 25,65 \\
\hline L. Leucocephala & 20 & 5,13 & 15,96 \\
\hline Flour Corn & 25 & 1,97 & 20,94 \\
\hline Bran pollard & 10 & 1,64 & 7,48 \\
\hline Total & 100 & 14,36 & 70,03 \\
\hline & & &
\end{tabular}

\section{Adaptation to FEed}

The male Kacang goats were adapted to complete silage for 14 days ( 2 weeks) before data collection. The aim was not only to eliminate the effects of previous feeds but also to obtain a stable body condition. Feeding was done twice a day, at 8:00 a.m. and 4:00 p.m. Central Indonesia Time . Drinking water was given ad libitum during the study.

\section{Data COLLECTION}

The study was conducted for 90 days including complete silage preparation phase, adaptation and data collection. Feeding was adjusted to the male Kacang goats body weight. Health control was carried out by cleaning and bathing, as well as conducting observation on the male Kacang goats which were likely to develop disease. The male Kacang goats were given Wormectin at a dose of 0.5 $\mathrm{ml} / 25 \mathrm{~kg} /$ day intramuscularly, to avoid infections of skin diseases such as scabies and internal parasites such as worms. Precautions for transmission were also carried out on uninfected male Kacang goats by giving the same dose of Wormectin.

The silage given was weighed and recorded, as was the rest of the silage to determine the amount of feed intake. Nutrients Composition of complete silage was known by taking $500 \mathrm{~g}$ of silage sample. It was then dried by the sun to a constant weight and ground with $1 \mathrm{~mm}$ mesh wiley mill. Its nutrients composition was analyzed in the laboratory.

Weighing the male Kacang goats to get the body weight was done on each goat at the beginning of the study. The next weighing was carried out every week to adjust the amount of feed given, and to find out the daily body weight gain, as well as the growth patterns of the male Kacang goats. 
Stool collection was conducted by total collection in the last week before the end of the study for 10 days to determine the feed digestibility. Before stool collection process, the male Kacang goats were placed in a metabolic cage equipped with different feed and drinking containers, which had been equipped with a stool container. Stool was collected daily and its fresh weight was weighed. Additionally, a 20\% sample was taken and sprayed with $10 \%$ formalin solution to avoid decomposition. The collected stool was then dried under the sun to a constant weight. The total stool that had been collected for 10 days was mixed evenly; $20 \%$ of which was taken and ground with $1 \mathrm{~mm}$ mesh wiley mill. Last but not least, it was brought to the laboratory for proximate analysis.

\section{VARIABLE MEASUREMENT}

The variables observed in this study included feed intake, digestibility, and growth performance of the male Kacang goats. Feed intake measured included the intake of dry matter (DM), crude protein $(\mathrm{CP})$, crude fiber $(\mathrm{CF})$, organic matter $(\mathrm{OM})$, nitrogen-free extract $(\mathrm{NFE})$ and energy. The DM intake was calculated by counting the difference between the amount of the feed given and the remaining feed. It was then multiplied by the DM of the feed (Hamidah et al., 2011). The intake of CP, CF, OM, $\mathrm{NFE}$ and energy was calculated by multiplying DM intake by the nutrients content (\%) of each of these feed nutrients.

The DM digestibility and feed nutrients were calculated by counting the difference between the intake of feed nutrients (DM, OM, CP, and CF) and fecal/stool nutrients (DM, $\mathrm{OM}, \mathrm{CP}$, and $\mathrm{CF}$ ). The equation was DM digestibility (\%) $=$ DM Intake - Stool DM/DM Intake $\mathrm{x}$ 100\% (Somanjaya et al., 2016).

Daily Body Weight Gain (DBWG) was obtained by finding the difference between the results of weighing the male Kacang goats (final body weight) and the previous body weight (initial body weight) divided by the research duration. The equation was DBWG $(\mathrm{kg})=$ final body weight $(\mathrm{kg})$ - initial body weight $(\mathrm{kg}) / \mathrm{observation}$ time (days). Feed conversion was obtained by comparing dry matter intake with the daily body weight gain of the male Kacang goats (Hamidah et al., 2011): Feed Conversion= DM Intake (g)/DBWG (g). Feed efficiency was obtained by comparing daily body weight gain with dry matter intake multiplied by 100\% (Irwanto and Mukhtiani, 2019). Feed efficiency= DBWG (g)/DM Intake (g)x 100\%.

\section{Data ANALYSIS}

Data were processed and analyzed with the Analysis of Variance (ANOVA). If the treatment had a significant effect, it was followed by the Duncan's Multiple Range Test based on the instructions of Gomez and Gomez (2010). Statistical Product and Service Solution (SPSS) Version 20 was utilized to facilitate data processing.

\section{RESULTS AND DISCUSSION}

\section{FEed INTAKe}

The results showed that the treatment had no significant effect $(\mathrm{P}>0.05)$ on DM intake and organic matter. DM intake of T1 treatment was $557.57 \pm 222.90 \mathrm{~g} / \mathrm{head} / \mathrm{day}$, T2 treatment was $627.69 \pm 168.07 \mathrm{~g} / \mathrm{head} /$ day, and T3 treatment was $568.25 \pm 112.00 \mathrm{~g} / \mathrm{head} /$ day. OM intake of $\mathrm{T} 1$ treatment was $483.68 \pm 193.10 \mathrm{~g} / \mathrm{head} /$ day, T2 treatment was $553.74 \pm 150.09 \mathrm{~g} / \mathrm{head} /$ day, and T3 treatment was $482.21 \pm 95.55 \mathrm{~g} / \mathrm{head} /$ day (Table 3 ).

The intake of $\mathrm{CP}, \mathrm{CF}$ and $\mathrm{EE}$ of the male Kacang goats given complete silage composed of several different forages was relatively similar between the treatments. The $\mathrm{CP}$ intake in T2 treatment was $86.93 \pm 24.06 \mathrm{~g} / \mathrm{head} /$ day, followed by T3 treatment which was $63.20 \pm 12.85 \mathrm{~g} / \mathrm{head} /$ day, and the lowest was in T1 treatment that was $54.84 \pm 21.10 \mathrm{~g} /$ head/day. The highest CF intake was in T1 treatment at

Table 3: Intake of Dry Matter (DM) and nutrients of the male Kacang goats fattened by complete silage'.

\begin{tabular}{|c|c|c|c|}
\hline \multirow[t]{2}{*}{ Variable } & \multicolumn{3}{|c|}{ Treatment } \\
\hline & $\mathrm{T} 1^{2}$ & $\mathrm{~T} 2^{3}$ & $\mathrm{~T} 3^{4}$ \\
\hline Dry matter intake (g/head/day) ${ }^{\text {ns }}$ & $557.57 \pm 222.90$ & $627.69 \pm 168.07$ & $568.25 \pm 112.00$ \\
\hline Organic matter intake (g/head/day) ${ }^{\text {ns }}$ & $483.68 \pm 193.10$ & $553.74 \pm 150.09$ & $482.21 \pm 95.55$ \\
\hline Crude protein intake $(\mathrm{g} / \mathrm{head} / \text { day })^{\mathrm{ns}}$ & $54.84 \pm 21.10$ & $86.93 \pm 24.06$ & $63.20 \pm 12.85$ \\
\hline Crude fiber intake ( $\mathrm{g} / \mathrm{head} /$ day) ${ }^{\mathrm{ns}}$ & $154.73 \pm 71.43$ & $93.16 \pm 26.37$ & $125.03 \pm 25.65$ \\
\hline Ether extract intake (g/head/day) ns & $29.55 \pm 12.64$ & $46.19 \pm 14.79$ & $39.51 \pm 7.20$ \\
\hline NFE intake (g/head/day) ${ }^{\text {ns }}$ & $244.22 \pm 89.32$ & $327.45 \pm 86.96$ & $254.46 \pm 53.67$ \\
\hline Gross Energy $(\mathrm{MJ})^{\mathrm{ns}}$ & $9.24 \pm 3.70$ & $10.96 \pm 3.00$ & $9.44 \pm 1.85$ \\
\hline Gross Energy (Kcal/kg.DM) ns & $2201.79 \pm 880.98$ & $2609.42 \pm 715.99$ & $2248.84 \pm 440.88$ \\
\hline $\mathrm{ME}(\mathrm{Kcal} / \mathrm{kg} . \mathrm{DM})^{\mathrm{ns}}$ & $1512.76 \pm 574.22$ & $2127.31 \pm 586.08$ & $1671.78 \pm 337.50$ \\
\hline
\end{tabular}

${ }^{1}$ Data are presented in the average $\pm \mathrm{SD} ; \mathrm{T}^{2}=$ Complete silage with natural grass-based forage; $\mathrm{T}^{3}=$ Complete silage with Sorghum bicolor L. Moench-based forage; T3 ${ }^{4}=$ Complete silage with Pennisetum purpuphoides-based forage. ${ }^{\text {ns }}=$ not significant . 
$154.73 \pm 71.43 \mathrm{~g} / \mathrm{head} /$ day followed by T3 treatment at $125.03 \pm 25.65 \mathrm{~g} / \mathrm{head} /$ day and the lowest was in T2 treatment at $93.16 \pm 26.37 \mathrm{~g} / \mathrm{head} /$ day. The $\mathrm{EE}$ intake in $\mathrm{T} 1$ treatment was lower at $29.55 \pm 12.64 \mathrm{~g} / \mathrm{head} /$ day than T2 and T3 treatments at $46.19 \pm 14.79 \mathrm{~g} / \mathrm{head} /$ day and $39.51 \pm 7.20 \mathrm{~g} / \mathrm{head} /$ day. Although the $\mathrm{CP}$ intake in all treatments was the same, it numerically showed that the $\mathrm{CP}$ intake was in line with the CP content in the feed (Table 1).

The intake of NFE and energy in this study was relatively similar between treatments. The NFE intake in T1 treatment was $244.22 \pm 89.32 \mathrm{~g} / \mathrm{head} / \mathrm{day}$, T2 treatment was $327.45 \pm 86.96 \mathrm{~g} / \mathrm{head} /$ day, and $\mathrm{T} 3$ treatment was $254.46 \pm 53.67 \mathrm{~g} / \mathrm{head} /$ day; energy intake (GE) (Kcal/ kg.DM) in T1 treatment was $2201.79 \pm 880.98$; T2 was $2609.42 \pm 715.99$ and T3 treatment was $2248.84 \pm 440.88$; while $\mathrm{ME}$ intake (Kcal $/ \mathrm{kg} . \mathrm{DM})$ in $\mathrm{T} 1$ treatment was $1512.76 \pm 574.22$; $\mathrm{T} 2$ treatment was $2127.31 \pm 586.08$; and T3 treatment was $1671.78 \pm 337.50$.

\section{NUTRIENTS DIGESTIBILITY}

Digestibility of DM and OM in ruminants basically describes the performance of rumen microorganisms and enzymes in the digestive tract. The high digestibility value indicates that the feed provided has a high quality. The results showed that DM and OM digestibility of the male Kacang goats given complete silage composed of different forages relatively similar between treatments. The DM Digestibility of T1 treatment was $88.27 \pm 3.75 \%$; T2 was $85.27 \pm 1.80 \%$ and T3 was $84.28 \pm 5.17 \%$; while OM digestibility of $\mathrm{T} 1$ treatment was $88.79 \pm 3.60$; $\mathrm{T} 2$ treatment was $85.19 \pm 1.82$; and T3 treatment was $84.57 \pm 5.12 \%$ (Table 4).

Digestibility of CP, CF, and NFE obtained from this study was relatively similar between treatments. In contrast, the treatment had a significant effect $(\mathrm{P}<0.05)$ on $\mathrm{EE}$ digestibility (Table 4).The digestibility range of each nutrient (\%) was CP ranging from $91.92 \pm 1.22-92.37 \pm 2.95 \%, \mathrm{CF}$ ranging from $69.33 \pm 10.29-80.33 \pm 6.17$; NFE ranging from $88.51 \pm 3.53-85.89 \pm 4.37 \%$. The digestibility of extract ether of $\mathrm{T} 1$ treatment was $93.12 \pm 2.14 \%$; $\mathrm{T} 2$ treatment was $85.37 \pm 3.31$, and $\mathrm{T} 3$ treatment was $81.71 \pm 8.58 \%$.

\section{GROWTH PERFORMANCE}

Daily body weight gain is a reflection of the accumulation of intake, fermentation, metabolism and absorption of food substances in the body (Simanihuruk and Sirait, 2010). The results of the study (Table 5) showed that the young male Kacang goats fattened by complete silage composed of natural grass (T1), Sorghum bicolor L. Moench (T2) and Pennisetum purpuphoides (T3) had a significant effect $(\mathrm{P}<0.05)$ on DBWG. Daily body weight gain of T2 treatment higher than $\mathrm{T} 1$ treatment $(\mathrm{P}<0.05)$, but was relatively the same with $\mathrm{T} 3$ treatment. As well as the T1 treatment was relatively the same with T3 treatment. The DBWG value of each treatment was T2 treatment with DBWG of $44.19 \pm 26.50 \mathrm{~g} / \mathrm{head} /$ day, followed by T3 treatment with DBWG of $20.98 \pm 11.69 \mathrm{~g} / \mathrm{head} /$ day, and T1 treatment with DBWG of $14.71 \pm 2.91 \mathrm{~g} / \mathrm{head} /$ day.

Conversion and feed efficiency obtained in this study were relatively similar between treatments (Table 5). Feed conversion value ranged from $18.45 \pm 9.88-53.38 \pm 59.76$; while the efficiency of the resulting feed ranged from $2.99 \pm 1.43-6.71 \pm 3.56 \%$. The feed conversion and efficiency values obtained in this study were not optimal since the increase in DM intake was not followed by a maximum increase in DBWG. Thus, the economic efficiency of this study was low because more feed was needed to produce one unit of body weight.

\section{Feed intake}

The results of study showed that the intake of feed ingredients was not much different between the three treatments. This illustrates that the quality of the three complete silage types given to livestock is not much different. As a result, the response of livestock to consume them is also relatively the same.

Table 4: Digestibility of dry matter (DM) and nutrients of the male Kacang goats fattened by complete silage ${ }^{1}$.

\begin{tabular}{llll} 
Observation variable & \multicolumn{3}{c}{ Treatment } \\
& $\mathrm{T}^{2}$ & $\mathrm{~T}^{3}$ & $\mathrm{~T}^{4}$ \\
\hline DM digestibility $(\%)^{\mathrm{ns}}$ & $88.27 \pm 3.75$ & $85.27 \pm 1.80$ & $84.28 \pm 5.17$ \\
OM digestibility (\%) $^{\mathrm{ns}}$ & $88.79 \pm 3.60$ & $85.19 \pm 1.82$ & $84.57 \pm 5.12$ \\
\hline CP digestibility (\%) & $92.04 \pm 2.58$ & $91.92 \pm 1.22$ & $92.37 \pm 2.95$ \\
CF digestibility (\%) & $80.33 \pm 6.17$ & $74.67 \pm 3.70$ & $69.33 \pm 10.29$ \\
EE digestibility (\%) & $93.12 \pm 2.14^{\mathrm{n}}$ & $85.37 \pm 3.31^{\mathrm{ab}}$ & $81.71 \pm 8.58^{\mathrm{b}}$ \\
NFE digestibility (\%) & $88.51 \pm 3.53$ & $85.88 \pm 1.79$ & $85.89 \pm 4.37$
\end{tabular}

${ }^{1}$ Data are presented in the average $\pm \mathrm{SD}$; $\mathrm{T}^{2}=$ Complete silage with natural grass-based forage; $\mathrm{T}^{3}=$ Complete silage with Sorghum bicolor L. Moench-based forage; T3 ${ }^{4}=$ Complete silage with Pennisetum purpuphoides-based forage. ${ }^{\text {a,b, }}$ Values with different superscripts in the same line show significantly different effects $(\mathrm{P}<0.05) .{ }^{\mathrm{ns}}=$ not significant. 
Table 5: Average of daily body weight gain (DBWG), feed conversion and feed efficiency of the male kacang goats fattened by complete silage ${ }^{1}$.

\begin{tabular}{|c|c|c|c|}
\hline Variable & $\mathrm{T} 1^{2}$ & $\mathrm{~T} 2^{3}$ & $\mathrm{~T} 3^{4}$ \\
\hline Initial body weihgt $(\mathrm{kg})^{\mathrm{ns}}$ & $13.13 \pm 3.74$ & $12.65 \pm 1.83$ & $12.70 \pm 0.95$ \\
\hline Final body weight $(\mathrm{kg})^{\mathrm{ns}}$ & $14.38 \pm 3.13$ & $15.13 \pm 2.17$ & $13.88 \pm 1.32$ \\
\hline DBWG (kg/head/day) & $14.71 \pm 2.91^{\mathrm{b}}$ & $44.19 \pm 26.50^{a}$ & $20.98 \pm 11.69^{a}$ \\
\hline Feed Conversion ${ }^{\text {ns }}$ & $37.79 \pm 12.33$ & $18.45 \pm 9.88$ & $53.38 \pm 59.76$ \\
\hline Feed Efficiency $(\%)^{\text {ns }}$ & $2.99 \pm 1.43$ & $6.71 \pm 3.56$ & $3.66 \pm 2.48$ \\
\hline
\end{tabular}

${ }^{1}$ Data are presented in the average $\pm \mathrm{SD} ; \mathrm{T}^{2}=$ Complete silage with natural grass-based forage; $\mathrm{T}^{3}{ }^{3}=$ Complete silage with Sorghum bicolor L. Moench-based forage; $3^{4}=$ Complete silage with Pennisetum purpuphoides-based forage. ${ }^{\mathrm{n}}=$ not significant; ${ }^{\mathrm{a}, \mathrm{b}}$ different superscripts on the same line show differences $(\mathrm{P}<0.05)$.

Besides, it is influenced by the same type, weight, and palatability of livestock, resulting in the same intake power. Furthermore, another thing that also influenced DM intake was the energy needs that had been fulfilled by the male Kacang goats, that they would stop to eat if the energy needs had been fulfilled. On the other hand, the relatively the same OM intake was caused by DM intake which had no significant effect. Organic matter was related to dry matter (Setyono et al., 2019); if dry matter intake was high, organic matter was too. OM intake in the T2 treatment was higher as a result of high DM intake of complete silage. It is in line with a research conducted by Widyobroto et al. (2016) that intake of organic matter is positively correlated with dry matter intake.

The relatively similar increase in the intake of dry matter and organic matter showed that the quality of complete silage from the three treatments was not much different. Moreover, the palatability of complete silage used was also quite good, so that the preference value (palatability) of goats for intake did not decrease. The palatability of complete silage could be reflected on its texture, taste, color and aroma produced which could stimulate the male Kacang goats to consume it. The DM intake in this study was slightly lower than the results of a research conducted by Tahuk et al. (2008) which found DM intake of Bligon goats fattened by feed containing different levels of crude protein ranging from $576.13-637.57 \mathrm{~g} / \mathrm{head} /$ day. This difference was caused by variations in livestock type, body weight, and different feed formulations.

Results of the study indicated the higher the $\mathrm{CP}$ content in the complete silage can have a positive impact on increasing consumption of crude protein. The $\mathrm{CP}$ intake in this study was also related to the intake of DM and OM, meaning that high or low DM intake would result in high or low $\mathrm{CP}$ intake. Consequently, it also had an impact on the high or low of basic living needs and production.

The protein content of feed is positively correlated with the intake of DM, OM, protein and energy (Sultan et al., 2009). The protein intake is also in accordance with
DBWG since basically protein is used to fulfill basic living needs. The range of protein intake $54.84-86.93 \mathrm{~g} / \mathrm{head} /$ day has fulfilled the CP requirement adequacy standard that is $56-58 \mathrm{~g} / \mathrm{head} /$ day (Suparjo et al., 2011)

The CF intake was relatively the same due to the analysis results of the different silage ingredients (Table 1). The CF content in natural grass $(28.22 \%)$ was higher than Pennisetum purpuphoides (26.34\%) and Sorghum bicolor L. Moench (23.32\%). Likewise, the total CF content of complete silage with natural grass-based forage was $27.26 \%$, while the CF content of complete silage with Pennisetum purpuphoides-based forage and Sorghum bicolor L. Moenchbased forage were $22.05 \%$ and $14.86 \%$ respectively. The higher the $\mathrm{CF}$ content in the three types of forage and complete silage produced, the higher the $\mathrm{CF}$ intake in the male Kacang goats. Suparjo et al. (2011) affirms that the $\mathrm{CF}$ intake will get higher if the $\mathrm{CF}$ content in the ration is also high and vice versa.

Furthermore, the EE intake was relatively similar because the ability of microorganisms to digest fat was not much different between treatments. The EE intake in this study was in line with the $\mathrm{EE}$ content in the complete silage. The EE content of complete silage (Table 2) in T2 treatment was $7.29 \%$, T3 treatment was $6.98 \%$, and the lowest, T3 treatment was $5.23 \%$. The higher the EE content in the complete silage, the higher the EE intake.

Although the results of statistical tests showed no significant effect, the NFE intake in T2 treatment tended to be higher than T1 and T3 treatments. It was related to the higher NFE content in sorghum forage used as a base in making complete silage (Table 1). The NFE content of Sorghum bicolor L. Moench (52.41\%) was higher than Pennisetum purpuphoides (41.27\%) and natural grass (33.28\%).

Nitrogen-Free Extract consists of starches and simple sugars (Syahrir, 2011). Simple starches and sugars are used by microorganisms as a source of energy which can then have an impact on the growth of goats. The NFE intake obtained in this study was slightly lower than the results 
of a research reported by Dhalika et al. (2010) that gave complete nutrients containing various levels of sugarcane shoot hay in rams fattened by the NFE intake, ranging from 344.91-371.86 g/head/day. It was related to the NFE content of each ingredient, the complete feed given and the types of livestock used.

The results showed that the energy intake in general was sufficient to even exceed the needs of the male Kacang goats (10-12 months). ME for the maintenance needs of goats is $765 \mathrm{Kcal} / \mathrm{head} /$ day or $101.34 \mathrm{Kcal} / \mathrm{kg} \mathrm{BW}$ BW $^{0.75}$ (NRC, 1981). Thus, the ME intake of the male Kacang goats in this study had already exceeded the maintenance needs. ME excess which is used for basic living will be utilized for production purposes which are generally in the form of weight gain. The ME intake shown in Table 3 is in line with the DBWG shown in Table 5, that the higher the $\mathrm{ME}$ consumed by the male Kacang goats, the higher the DBWG produced.

\section{Nutrients DigeSTIBILITY}

The dry matter (DM) digestibility values ranged from 84.28-88.27\% and organic matter (OM) digestibility ranged from $84.57 \pm 5.12 \%-88.79 \pm 3.60 \%$ indicated that the use of complete silage contributed positively in fattening the male Kacang goats. The DM digestibility value in this study is higher than the results of a research conducted by Lawa et al. (2017) which obtained DM digestibility values ranging from $69.3 \pm 7.76-75.7 \pm 4.89 \%$ in the male Kacang goats given different levels of white kabesak in their feed. The variation of digestibility value in the goats is influenced by the type of feed, nutrients content of feed, as well as body weight.

Digestibility of organic matter (OM) which was relatively the same was affected by DM digestibility. The DM digestibility value theoretically has a significant influence on OM digestibility. If DM digestibility is not different, $\mathrm{OM}$ digestibility is too. The high and relatively equal digestibility of $\mathrm{OM}$ in all three treatments was due to increased nutritional value in complete silage due to the addition of soluble carbohydrate sources.

The addition of soluble carbohydrates can increase the performance of rumen microbes in digesting feed. The high digestibility of DM and OM in this study reflected the large contribution of nutrients to the male Kacang goats to increase their productivity. High and low digestibility of feed in livestock was influenced by the amount of feed given. Digestibility of feed ingredients is low if the amount of feed given to livestock is also limited (Aryanto and Panjono, 2013).

High or low digestibility of feed ingredients is influenced by several factors including the chemical composition of the ration, the physical form of the ration, and the level of feeding (McDonald et al., 2010). The addition of sources of easily degraded carbohydrates such as corn flour and bran pollard with the same percentage in the production of silage have an impact on the quality of the same complete silage, thus allowing the growth of the same microbes in digesting the complete silage given. Kurniawati (2007) points out that the addition of carbohydrate and protein sources that are easily degraded can increase the growth of rumen microbes that produce VFA.

The high digestibility of feed nutrients in this study illustrated that the use of complete silage could provide nutrients that could be utilized by the male Kacang goats to meet their needs both for maintenance and for production. Moreover, the high digestibility value showed that the 3 types of complete silage given to the male Kacang goats had not much different quality. The proportion of Leucaena leucocephala as protein source feed ingredients used to make complete silage for each treatment was the same (25\%). As a result, it had relatively the same effect between treatments.

Digestibility of CP in this study was directly proportional to the $\mathrm{CP}$ intake (Table 3 ) and the $\mathrm{CP}$ content in complete silage (Table 2). According to Ariwibawa et al. (2015), the high DM intake in feed will produce high amounts of $\mathrm{OM}$ and digestible CP. Digestibility value of crude protein can also increase body weight gain, where the higher the $\mathrm{CP}$ digestibility, the higher the DBWG produced. It is supported by a notion stated by Yulianti et al. (2019) that the higher the digestibility coefficient of crude protein can have an impact on increasing livestock body weight. The protein in the animal's body will be transformed into amino acids, which are then used by microorganisms as a source of the $\mathrm{N}$ framework to carry out activities in the rumen. Dead microorganisms that enter the intestine can be a source of protein for the host (Padang, 2005).

High or low of CF digestibility is influenced by the crude fiber content of feed. If the crude fiber content is high, its digestibility is too. In this study, although CF digestibility was relatively similar, $\mathrm{CF}$ digestibility of complete silage with natural grass-based forage tended to be higher than CF digestibility of complete silage composed of Sorghum bicolor L. Moench and Pennisetum purpuphoides forages. Padang (2005) believes that CF digestibility of feed depends on the composition of the feed. Besides the rumen microbial population, the digestibility value in ruminant animals is strongly influenced by the crude fiber content of feed. Furthermore, according to Morais et al. (2018), crude fiber is one of the sources of energy for the growth of rumen microbes. Maximum population development microbes in rumen will have an impact on increasing digestive activity of feed. 
Additionally, EE digestibility in T1 treatment was higher than T3, but it was relatively the same as in T2 treatment. High digestibility in both treatments contributed to the increase in energy reserves obtained by the male Kacang goats to increase productivity. The increased digestibility of $\mathrm{EE}$ also illustrated the adequacy of the $\mathrm{N}$ and $\mathrm{C}$ frameworks as sources of protein and energy to increase growth and activity of rumen microbes in digesting nutrients.

The digestibility value of EE shown (Table 4) which ranges from $81.71 \%-93.12 \%$ is quite high, and illustrates the true digestibility for crude fat which is above $80 \%$ (Suprapto et al., 2013). The digestibility value of crude fat in this study is the same as the results of research conducted by Silva et al. (2019) which obtained EE digestibility ranging from $80.12 \%-95.00 \%$. Therefore, it can be stated that the complete silage used in this study has a high enough quality. It is indicated by the high digestibility of feed nutrients, including EE.

Increased digestibility of NFE from the three treatment groups could increase carbohydrates or starch obtained by livestock to increase rumen microbial development and activity. Furthermore, it could also optimize the productivity of fattened goats. The results of this study indicate that complete silage is very potential to be used as quality feed ingredients to meet the nutritional needs of fattened goats, including the Kacang goats. According to Hernman et al. (2015), NFE is easier to digest than crude fiber. Thus, an increase in the digestibility value of NFE has a positive effect on increasing the easily digestible carbohydrates obtained by livestock.

\section{GROWTH PERFORMANCE}

The results of this study indicated that the silage composed of Sorghum bicolor L. Moench was able to increase the best DBWG of the male Kacang goats. The tendency of higher DBWG in T2 treatment indicated that the complete silage produced had higher nutritional content than complete silage in T1 and T3 treatments. The results of laboratory analysis showed that although the $\mathrm{CP}$ content of complete silage was not significantly different between treatments, the T2 treatment showed a tendency for higher $\mathrm{CP}$ and metabolic energy content than T1 and T3 which were $13.81 \%$ and $3382.52 \mathrm{Kcal} / \mathrm{kg}$ DM.

The balance of energy and protein of complete silage used could increase feed intake and digestibility, which in turn stimulated livestock growth. Siti et al. (2012) strongly advocates that sufficient balance of energy and protein can meet maintenance needs and livestock production, including for microbial needs and its activities in digesting feed.

In this study, even though feed intake and digestibility were quite high, the resulting DBWG was not maximal.
The DBWG target of $0.75 \mathrm{~g} / \mathrm{day}$ was not achieved yet. It was presumably influenced by the age of young goats, so the concentration of nutrients focused on increasing growth, not body tissue deposits, both muscle and fat. Moreover, the nutrients maintenance needs of the goats were probably higher so that the proportion of nutrients for production needs was lower.

The DBWG value produced in this study is lower than the results of a research conducted by Jaelani et al. (2014) which obtained DBWG of $48.82 \mathrm{~g} / \mathrm{head} /$ day for the male Kacang goats given haylage swamp forage; $50.00 \mathrm{~g} / \mathrm{head} /$ day for the male Kacang goats given fresh swamp forage; and $61.90 \mathrm{~g} /$ head/day the male Kacang goats given swamp forage silage. The difference in growth is caused by differences in the type of feed used and its quality, and the initial weight of the animal. The nutrients content of swamp forages in the fresh condition, haylage and silage is markedly higher than complete silage made from natural grass, Sorghum bicolor $L$. Moench and Pennisetum purpuphoides. Likewise, the initial body weight of the male Kacang goats used that the weight of the goats used in this study ranged from $9-11 \mathrm{~kg}$, while Jaelani et al. (2014) used the male Kacang goats with initial body weight of $11-14 \mathrm{~kg}$.

In general, the results showed that the feed conversion and efficiency of the three livestock groups that were given complete silage were not much different. Nevertheless, the male Kacang goats in T2 treatment tended to show better feed conversion and efficiency than the other two treatments. Theoretically, the smaller the conversion value produced, the more efficient the feed used by livestock for growth. In addition, the greater the conversion value, the less efficient the feed obtained by livestock for maximum growth. On the other hand, the greater the value of feed efficiency, the better the use of feed for the growth of the male Kacang goats. The high efficiency of feed shows that nutrients can be utilized for livestock productivity and growth (Restitrisnani et al., 2013).

The results of this study indicated that the giving of complete silage with different forage-based ingredients apparently did not provide maximum results on livestock growth. The quality of complete silage that was not much different between groups of livestock provided sufficient energy to meet maintenance needs than the production needs of the goats fattened. As a result, the conversion value and the resulting feed efficiency were not optimal and relatively the same between treatments.

\section{CONCLUSIONS AND RECOMMENDATIONS}

Nutrients intake and digestibility are generally the same 
for all treatments, except the digestibility of extract ether in the male Kacang goats fed complete silage-based sorghum forage (T2) was higher than other treatments. The daily body weight gain of the male Kacang goats given Sorgbum bicolor L. Moench can be increased, when compared to livestock groups that receive complete silage-based natural grass. On the other hand, the growth of livestock that received complete silage based on Pennisetum purpuphoides was not much different from the growth of livestock that received complete silage based on natural grass. Feed conversions and efficiency (\%) in all treated animals are relatively the same.

\section{ACKNOWLEDGEMENTS}

The researchers would like to express their deepest gratitude to the Institute of Research and Community Service (Indonesian: Lembaga Penelitian dan Pengabdian Masyarakat/LPPM), Universitas of Timor who has funded lecturer competency research activities with contract implementation numbers: 004 / UN60 / LPPM / PP / 2019, March 27, 2019.

\section{NOVELTY STATEMENT}

This study contributes to improving the performance of Kacang goats on dry land along the year both in quality and quantity through development technology of complete silages.

\section{AUTHOR'S CONTRIBUTION}

PKT and GFB designed research, statistical analysis and drafted the manuscript. KRML, ABN and NK assisted in the research process and data collection. All authors make significant contributions to research and have read and approved the final manuscript.

\section{CONFLICT OF INTEREST}

The authors have declared no conflict of interest.

\section{REFERENCES}

-Amrullah FA, dan Erwanto L (2015). The effect of addition various types of carbohydrate sources in silage vegetables waste to crude fat content, crude fiber, crude protein an non nitrogen free extract. J. Ilmiah Peternakan Terpadu., 3: 221227.

-Ariwibawa GP, Mudita IM, Wibawa AAPP (2015). The appereance of Bali cattle who given ration based on agricultural waste fermented by inoculan rumen liquid and termite. J. Trop. Anim. Sci., 3: 44-59.

-Aryanto B, dan Panjono S (2013). Effect of reduction and refulfillment of feed quantity on feed intake and nutrient digestibility of kacang and etawah crossbred goat.
Bull. Peternakan, 37: 12-18. https://doi.org/10.21059/ buletinpeternak.v37i1.1954

- Dhalika T, Setyowati EY, Nurachma S, Hidayati YA (2010). Nilai nutrisi ransum lengkap mengandung berbagai taraf hay pucuk tebu (Saccharum offocinarum) pada domba jantan yang digemukkan. J. Ilmu. Ternak, 10: 79-84.

- Gomez KA, Gomez AA (2010). Prosedur statistik untuk penelitian pertanian. Edisi Kedua. Jakarta (Indones): UI Press.

- Hamidah A, Sutrisno CI, Sunarso, Chrstiyanto M, Nuswantara LK, Muthalib RA (2011). Performance of fat-tailed rams fed complete feed base oil palm fronds. J. Indonesian Trop. Anim. Agric., 36: 185-189. https://doi.org/10.14710/ jitaa.36.3.185-189

- Harianingsih (2013). Bioconversion of cassava estate waste by anareob fermentation on local lambs performance. Indonesian J. Apll. Sci., 3: 33-37.

- Hartadi H, Reksohadiprodjo S, Lebdosukojo S, Tillman AD, Kearl LC, Harris LE (1980). Tables of feed composition for Indonesia. IFI., Utah Agricultural Experiment Station, Utah State University, Logan, UT., USA., pp. 12.

-Hernaman I, Budiman A, Nurachma S, Hidajat K (2015). Kajian in vitro subtitusi konsentrat dengan penggunaan limbah perkebunan singkong yang disuplementasi kobalt (Co) dan seng $(\mathrm{Zn})$ dalam ransum domba. Bull. Peternakan, 39: 7177. https://doi.org/10.21059/buletinpeternak.v39i2.6710

-Irwanto, Muktiani SA (2019). Pengaruh pemberian probiotik isi rumen dari berbagai ternak ruminansia terhadap penampilan produksi domba batibul. Bull. Appl. Anim. Res., 1: 15-20. https://doi.org/10.36423/baar.v2i1.187

- Jaelani A, Rostini T, Jonathan MIZ (2014). Pengaruh penggunaan hijauan rawa fermentasi terhadap penampilan kambing Kacang (Caprabircus). Sains Peternakan, 12: 76-85. https://doi.org/10.20961/sainspet.12.2.76-85

-Jasin I (2014). The effect of molasses and lactic acid bacteria isolated from rumen fluid of PO cattle on napier grass silage quality. Agripet., 14: 50-55. https://doi.org/10.17969/ agripet.v14i1.1205

- Kearl LC (1982). Nutrient requiments of ruminants in developing countries. Int. Feedstuff Inst. Utah Agric. Exp. Station Logan (USA): Utah State University.

-Kurniawan W, Syamsuddin, Salid WL, Isnaini PD (2019). Quality evaluation, fermentation characteristic and in vitro digestibility of stay green sorghum-gliricidia sepium mix silage on different level of lactic acid utilization. Agripet, 19: 99-106. https://doi.org/10.17969/agripet.v19i2.14857

-Kurniawati (2007). In-vitro gas production technique as for feed evaluation: Volume of gas production and feed degradibility. Sci. J. Appl. Isotopes Radiat., 3: 40-49.

-Lawa EDW, Marjuki, Hartutik, Chuzaemi S (2017). Effect of white kabesak (Acacia leucophloea Roxb) leaves level in the diet on feed intake and body weight gain of kacang goat. J. Indonesian Trop. Anim. Sci., 42: 255-262. https://doi. org/10.14710/jitaa.42.4.255-262

- McDonald P, Edwards RA, Greenhalgh JFD, Morgan CA (2010). Animal nutrition. $7^{\text {th }}$ Ed. New York: Longman.

- Morais MJ, Sevilla CC, Dizon JT, Manulat GL, Abes EEC, Angeles AA (2018). Growth performance and ruminal metabolic variables of goats fed rain tree (Samanea saman) pods. Trop. Anim. Sci.J., 41: 22-28. https://doi.org/10.5398/ tasj.2018.41.1.22

- National Research Council (NRC) (1981). Nutrient requirement of goats: Angora, dairy, and meat goat in temperate and 
tropical countries. Nutrient Requirements of Domestic Animal. Washington DC: National Academy Press.

- Padang (2005). Effect of long time feeding on dry matter, crude protein, and crude fiber digestibility of male kacang goat ration. J. Ilmu Ternak, 5: 88-93.

- Restitrisnani V, Purnomoadi, Rianto E (2013). The production and body composition of kacang goat fed different quality of diets. J. Indonesian. Trop. Anim. Sci., 38: 163-170. https:// doi.org/10.14710/jitaa.38.3.163-170

- Santoso B, Hariadi BTJ, Alimuddin, Seseray DY (2011). Fermentation quality and nutritive value of rice crop residue based silage ensiled with addition of epiphytic lactic acid bacteria. Indonesian J. Anim. Vet. Sci., 16: 1-8.

- Setyono W, Kustantinah K, Indarto E, Dono ND, Zuprizal Z, Zulfa IH (2019). Calliandra calothyrsus and Artocarpus heterophyllus an anti-parasite for bligon goat. J. Indonesian. Trop. Anim. Agric., 44: 400-407. https://doi.org/10.14710/ jitaa.44.4.400-407

-Silva G, Muhtarudin, Liman, Sutrisna R (2019). The effect of cassava waste and organic micro minerals on digestibility of crude fat and total digestible nutrient of male ettawa crossbreed goat. J. Riset. Inovasi Peternakan, 3: 20-24.

-Simanihuruk K, Sirait J (2010). Silase kulit buah kopi sebagai pakan dasar pada kambing Boerka sedang tumbuh. Seminar Nasional Teknologi Peternakan dan Veteriner. Bogor (Indones). Pusat Penelitian dan Pengembangan Peternakan. pp. 557-556.

- Siti NW, Sucipta IGMA, Mudita IM, Pratama IBG, Cakra IGLO (2012). The supplementation of urea molasses block for increasing performance of ettawah crossbred goats fed diet containing gliricidia spium green forage. Agripet, 12: 49-54. https://doi.org/10.17969/agripet.v12i2.203

- Somanjaya R, Rahmah UIL, Dani U (2016). Performance and digestibility of Garut sheep males on addition waste forage sorghum fermentation in the diets. CR J., 2(2): 147-162. https://doi.org/10.34147/crj.v2i02.34

- Sultan JI, Inam-Nur-Rahim, Yaqoob M, Mustafa MI, Nawaz
H, Akhtar P (2009). Nutritional evaluation of herbs as fodder source for ruminant. Pak. J. Bot., 41(6): 2765-2776.

- Suparjo KG, Wiryawan, Laconi EB, Mangunwidjaja D (2011). Goat performance fed with fermented cocoa pod husk. Media Peternakan, 34: 35-41. https://doi.org/10.5398/ medpet.2011.34.1.35

-Suprapto H, Suhartati FM, Widiyastuti T (2013). Kecernaan serat kasar dan lemak kasar completed feed limbah rami dengan sumber protein berbeda pada kambing peranakan etawa lepas sapih. J. Ilmiah Peternakan, 1: 938-946.

-Syahrir, 2011. Pengaruh pemberian kulit buah kakao fermentasi dengan tiga jamur berbeda terhadap konsumsi bahan kering dan kecernaan nutrien pakan pada kambing jantan. J. Agrisains, 12: 101-108.

-Tahuk PK, Baliarta E, Hartadi H (2008). Kinerja kambing Bligon pada penggemukan dengan level protein pakan berbeda. Bull. Peternakan, 32: 121-135. https://doi, org/10.21059/buletinpeternak.v32i2.1250

-Tahuk PK, Dethan AA (2010). Performance of Bali bull in greenlot fattening by farmers when rainy season in Timor Island. J. Indonesian Trop. Anim. Agric., 35: 257-261. https://doi.org/10.14710/jitaa.35.4.257-261

-Tahuk PK, Bira GF (2020). Carcass and meat characteristics of male Kacang goat fattened by complete silage. Vet. World, 13(4): 706-715. https://doi.org/10.14202/ vetworld.2020.706-715

-Widyobroto BP, Rochijan, Ismaya, Adiarto, Suranindyah YY (2016). The impact of balanced energy and protein supplementation to milk production and quality early lactating dairy cows. J. Indonesian Trop. Anim. Agric., 41: 83-90. https://doi.org/10.14710/jitaa.41.2.83-90

-Yulianti G, Dwatmadji, Suteky T (2019). Digestibility of crude protein and crude fiber of male Etawa crossbreed goat fermented tofu waste and palm kernel cake with different ratio. J. Sain Peternakan Indonesia, 14: 272-281. https://doi. org/10.31186/jspi.id.14.3.272-281 